\title{
Simulation Model in Markovian Decision Theory in Allocation Optimization in Nigerian River Basin Development
}

\author{
Dr. Eme Luke Chika, (B.Sc, PGD, PGDE, M.Eng, Ph.D), \\ Civil Engineering Department, Chukwuemeka Odumegwu Ojukwu University \\ (formerly Anambra State University), Uli - Nigeria \\ Ohaji Evans, (B.Eng, M.Eng) \\ Rural Infrastructural Engineer, Implementation Field Office, \\ Niger Delta Support Programme Component, Imo State, Nigeria
}

\begin{abstract}
The work applied Simulation Modeling in Markovian Decision Theory, adapts infinite models of exhaustive enumeration method for the solution of allocation optimization in multi-purpose and multi-objective Nigerian River Basin Development Authorities, RBDAs' planning and management problems by logically apportioning levels of development to various purposes while optimizing eight objectives in stages. This type of management problem is a decision problem and cannot be handled by linear programming which can only optimize one objective at a time. Methodology involves methods and experiments, data were collected from the River Basin Development Authorities, Ministries and Parastatals. Markov chain was used to assess solution. The result of the experiments shows policy 10, worst conflict condition calls for application of maintenance whenever the River Basin Engineering Development is in state 8 or very poor which interprets that development should be logically apportioned by the planning and management engineer as follows: Irrigated Agriculture-N3.86b, Water SupplyN8.82b, Hydropower-N13.42b, Flood Control-N17.52b, Drainages-N23.16b, Navigation-N25.58b, RecreationN45.84b, Erosion Control-N61.84b. While $\mathrm{E}^{10}$ represents expected yearly benefit: when the River Basin Engineering Development is apportioned as above stated from the limited available fund of the Federal Government Budget of $\mathrm{N} 200 \mathrm{billon}$, at least a (revenue) benefit of $\$ 1$ 1.108Trillion can be achieved under the worst condition of conflict objectives. This work also advises a maintenance programme for the River Basin in accordance with the result of experiments because the Basin should operate a minimum of 8years and a maximum of 21 year for full capacity utilization of assets.
\end{abstract}

Keywords: Simulation, allocation, optimization, Markov chain, River Basin Development

DOI: $10.7176 / \mathrm{JRDM} / 53-05$

Publication date:March $31^{\text {st }} 2019$

\subsection{Introduction}

Previous works on multi-purpose Nigerian River Basin Engineering Development project planning with regard to optimization have considered a single objective; this objective in question is economic optimization, Ojiako (1985). However, in real life situation this is not always the case; other objectives can play significant roles along-side economic efficiency to determine levels of development to be apportioned to various purposes involved in water resources projects. Such other objectives include: Regional Economic Redistribution, Local Economic Redistribution, State Economy Redistribution, Federal Economic Redistribution, Environmental Quality Improvement, and Youth Employment. These objectives are becoming increasingly important due to somepolitical, ecological, health and because, the singular objective had led to cases of kidnapping, vandalization, disagreement between the Federal Government, planning engineers and interest groups during project authorization.

Consequently, other objectives cannot be ignored in thorough planning. Thus, the planning engineer has considered benefits accruing from objectives outside economic efficiency as either too difficult and too abstract to measure or intangible. However, the fact is that these other objectives are considered very vital by interest groups at the level of authorization, Divine (1966).Hence, the myth of immeasurability and intangibility of benefits accruing from them must be destroyed. Scientifically, all measures are relative. Therefore, intangibility and immeasurability cannot be in absolute terms. Hence, there must be a measure for a benefit that exits. As a matter of fact, a thorough analysis of benefits in the light of, dams in the multi-purpose Nigerian River Basin development project can show that tangible benefits are accruable under each of the objectives. It can also be plausible to consider the benefit accruable by each purpose (development) to vary with respect to each objective, table 2 and 3. Moreover this point can be buttressed by data available from such areas of learning as social, statistics, medical, geography, welfare, ecology, and environmental engineering. In view of the foregoing, it becomes necessary in multi-purpose water resources planning to consider not only economic efficiency but also any other objectives that may be deemed necessary at planning stage for explicit, exhaustive and effective decision making.

In the same vein, it is necessary to look at simulation modeling in allocation optimization in multi-purpose 
water resources projects from the point of view of multi-objectivity. Then, we can set our mind on resolving the engineering conflict situation arising from it with markovian decision theory and the overall performance of the system.

The problems were particularly acute in Anambra and Imo Basin Authority areas which are known to have the highest population density in Africa. The problems centered chiefly around non-availability of arable land for re-settlement of displaced Communities from a planned reservoir or dam site and the huge financial outlay required if adequate compensation to the displaced families are to be paid. Negotiations often took much time and in some cases this created the bottleneck in the construction of development work. The RBDAs had to pay the compensations and resettlement expenditures from their financial allocations, table 1 and they were often hardly left with any substantial capital for project development of the resource.

Table 1 The Inadequate Allocation to the Eleven Nigerian River Basin Development Authorities

\begin{tabular}{|l|l|l|l|l|}
\hline S/no & $\begin{array}{l}\text { River Basin Development } \\
\text { Authorities (R.B.D.A) }\end{array}$ & $\begin{array}{l}\text { Estimated Cost of } \\
\text { Development projects } \\
(1981-85) \\
\text { Million \# }\end{array}$ & $\begin{array}{l}\text { "Allocation by National } \\
\text { Planning Committee } \\
(1981-85) \\
\text { Million \# }\end{array}$ & $\begin{array}{l}\text { \% } \\
\text { Capital } \\
\text { Available }\end{array}$ \\
\hline 1. & Anambra/Imo R.B.D.A & 355.00 & 105.00 & 29.58 \\
2. & Benin- Owena R.B.D.A & 238.58 & 135.00 & 56.59 \\
3. & Chad R.B.D.A & 506.225 & 170.00 & 33.58 \\
4. & Cross River R.B.D.A & 247.00 & 78.56 & 31.82 \\
5. & Hadejia/Jama'are R.B.D.A & 410.00 & 127.00 & 30.98 \\
6. & Lower Benue River R.B.D.A & 481.00 & 102.00 & 21.21 \\
7. & Niger R.B.D.A & 582.50 & 146.00 & 25.06 \\
8. & Niger Delta R.B.D.A & 470.076 & 85.00 & 18.08 \\
9. & Ogun - Oshun R.B.D.A & 213.72 & 145.00 & 67.85 \\
10. & Sokoto /Tima R.B.D.A & 702.49 & 597.00 & 84.98 \\
11. & Upper Benue R.B.D.A & 480.74 & 118.00 & 24.55 \\
\hline
\end{tabular}

Table 2 with maintenance, (net) benefits to N200billion under various objectives (NX10)

\begin{tabular}{|l|l|l|l|l|l|l|l|l|}
\hline $\begin{array}{l}\text { Purposes } \\
\text { (development) }\end{array}$ & \multicolumn{9}{|c|}{ Objectives } \\
\hline & $\begin{array}{l}\text { Economic } \\
\text { Efficiency }\end{array}$ & $\begin{array}{l}\text { Federal } \\
\text { Economic } \\
\text { Redistribu- } \\
\text { Tion }\end{array}$ & $\begin{array}{l}\text { Regional } \\
\text { Economic } \\
\text { Redistribu- } \\
\text { tion }\end{array}$ & $\begin{array}{l}\text { State } \\
\text { Economic } \\
\text { Redistribu- } \\
\text { tion }\end{array}$ & $\begin{array}{l}\text { Local } \\
\text { Economic } \\
\text { Redistribu- } \\
\text { Tion }\end{array}$ & $\begin{array}{l}\text { Social } \\
\text { Well- } \\
\text { Being }\end{array}$ & $\begin{array}{l}\text { Youth } \\
\text { Employ- } \\
\text { ment }\end{array}$ & $\begin{array}{l}\text { Environ } \\
\text { mental } \\
\text { Quality } \\
\text { Improve- } \\
\text { ment }\end{array}$ \\
\hline $\begin{array}{l}\text { Irrigation } \\
\text { Agriculture }\end{array}$ & 4.0 & 3.0 & 12.2 & 3.0 & 2.5 & 4.8 & 4.0 & 4.9 \\
\hline Water supply & 3.0 & 2.0 & 7.0 & 3.0 & 10.0 & 6.8 & 3.0 & 6.8 \\
\hline $\begin{array}{l}\text { Hydro electric } \\
\text { Power } \\
\text { Generation }\end{array}$ & 63.0 & 9.0 & 9.0 & 10.0 & 9.9 & -3.0 & 2.8 & 4.0 \\
\hline Flood control & 5.0 & 18.5 & 6.0 & 3.0 & 2.6 & 2.0 & 3.0 & 4.2 \\
\hline Drainage & 24.0 & 5.0 & 6.0 & 3.8 & 3.4 & 2.2 & 3.8 & 3.2 \\
\hline Navigation & -30.0 & 4.0 & 7.0 & 1.0 & 6.7 & 8.0 & 4.0 & 4.8 \\
\hline Recreation & 4.0 & 3.0 & 6.0 & 3.0 & 2.6 & 2.5 & 3.5 & 9.0 \\
\hline $\begin{array}{l}\text { Erosion } \\
\text { Control }\end{array}$ & 16.0 & 5.0 & 8.0 & 2.8 & 2.5 & 3.0 & 3.8 & 4.2 \\
\hline
\end{tabular}


Table 3 without maintenance, (gross) benefits to 200 billion under various objective (NX10)

\begin{tabular}{|l|l|l|l|l|l|l|l|l|}
\hline $\begin{array}{l}\text { Purposes } \\
\text { (development) }\end{array}$ & \multicolumn{9}{|c|}{ Objectives } \\
& $\begin{array}{l}\text { Economic } \\
\text { Efficiency }\end{array}$ & $\begin{array}{l}\text { Federal } \\
\text { Economic } \\
\text { Redistribu- } \\
\text { Tion }\end{array}$ & $\begin{array}{l}\text { Regional } \\
\text { Economic } \\
\text { Redistribu- } \\
\text { tion }\end{array}$ & $\begin{array}{l}\text { State } \\
\text { Economic } \\
\text { Redistribu- } \\
\text { tion }\end{array}$ & $\begin{array}{l}\text { Local } \\
\text { Economic } \\
\text { Redistribu- } \\
\text { tion }\end{array}$ & $\begin{array}{l}\text { Social } \\
\text { Well- } \\
\text { Being }\end{array}$ & $\begin{array}{l}\text { Youth } \\
\text { Employ- } \\
\text { ment }\end{array}$ & $\begin{array}{l}\text { Environ } \\
\text { mental } \\
\text { Quality } \\
\text { Improve- } \\
\text { ment }\end{array}$ \\
\hline $\begin{array}{l}\text { Irrigation } \\
\text { Agriculture }\end{array}$ & 4.6 & 3.5 & 14.0 & 3.5 & 2.9 & 5.5 & 4.6 & 5.6 \\
\hline Water supply & 3.5 & 2.3 & 8.1 & 3.5 & 11.5 & 7.8 & 3.5 & 7.8 \\
\hline $\begin{array}{l}\text { Hydro } \\
\text { electric } \\
\text { Power } \\
\text { Generation }\end{array}$ & 72.5 & 10.4 & 10.4 & 12.5 & 11.4 & $(-3.5)$ & 3.2 & 4.6 \\
\hline Flood control & 5.8 & 21.3 & 6.9 & 3.5 & 3.0 & 2.3 & 3.5 & 4.8 \\
\hline Drainage & 27.6 & 5.8 & 6.9 & 4.4 & 3.9 & 2.5 & 4.4 & 3.76 \\
\hline Navigation & $(-34.5)$ & 4.6 & 8.1 & 1.2 & 7.7 & 9.2 & 4.6 & 5.5 \\
\hline Recreation & 4.6 & 3.5 & 6.9 & 3.5 & 3.0 & 2.9 & 4.0 & 10.4 \\
\hline $\begin{array}{l}\text { Erosion } \\
\text { Control }\end{array}$ & 18.4 & 5.8 & 9.2 & 3.2 & 2.9 & 3.5 & 4.4 & 4.8 \\
\hline
\end{tabular}

\subsection{Material and Methods}

Methodology involves methods and experiments, data were collected from the River Basin Development Authorities, Ministries and Parastatals. The steady-state behavior of a Markovian process is independent of the initial state of the system. This model is interested in evaluating policies for which the associated Markov chains allow the existence of a steady-state solution to provide the conditions under which a Markov chain can yield steady-state probabilities.

There are two methods for solving the infinite-stage problem. The first and best method calls for evaluating all possible stationary policies of the decision problem faced by the planning and managing engineer. This is an exhaustive enumeration process and can be used only if the number of stationary policies is reasonably small. Eme (2012) and Hamdy,(2008)

\subsection{Discussion of Results}

In exhaustive enumeration method, the decision problem faced by the engineer has total of S. stationary policies, and assume that $\mathrm{P}^{\mathrm{s}}, \mathrm{R}^{\mathrm{s}}$, are the (one-step) transition and revenue matrices associated with the policy, $\mathrm{S}=1,2, \ldots$, $\mathrm{S}$. The steps of the enumeration method are as follows,

Step 1. Compute $V^{i}{ }_{s}$, the expected one-step (one-period) revenue of policy $S$, given state $i, i=1,2 \ldots, m$

Step 2.Compute $\pi_{i}^{\mathrm{s}}$, the long-run stationary probabilities, when they exist, are computed from the equations.

$$
\begin{gathered}
\pi^{\mathrm{s}} \mathrm{P}^{\mathrm{s}}=\pi^{\mathrm{s}} \\
\pi_{1}^{\mathrm{s}}+\pi^{\mathrm{s}}+\ldots+\pi_{\mathrm{m}}^{\mathrm{s}}=1
\end{gathered}
$$

where $\pi^{\mathrm{s}}=\left(\pi_{1}^{\mathrm{s}}, \pi_{2}^{\mathrm{s}}, \ldots \pi_{\mathrm{m}}^{\mathrm{s}}\right)$.

Step 3Determine $E^{s}$ the expected revenue of policy $S$ per transition step (period), by using the formula.

$\mathrm{E}^{\mathrm{s}}=\sum_{\mathrm{i}=1}^{\mathrm{M}} \pi_{\mathrm{i}}^{\mathrm{s}_{\mathrm{i}} \mathrm{V}_{\mathrm{i}}^{\mathrm{s}}}$

Step 4. The optimal policy $S^{*}$ is determined such that $E^{s}=\operatorname{Max}\left\{E^{s}\right\}$

The matrices Ps and Rs for polices 8 through 21 are derived from these of policies 1 and 2 


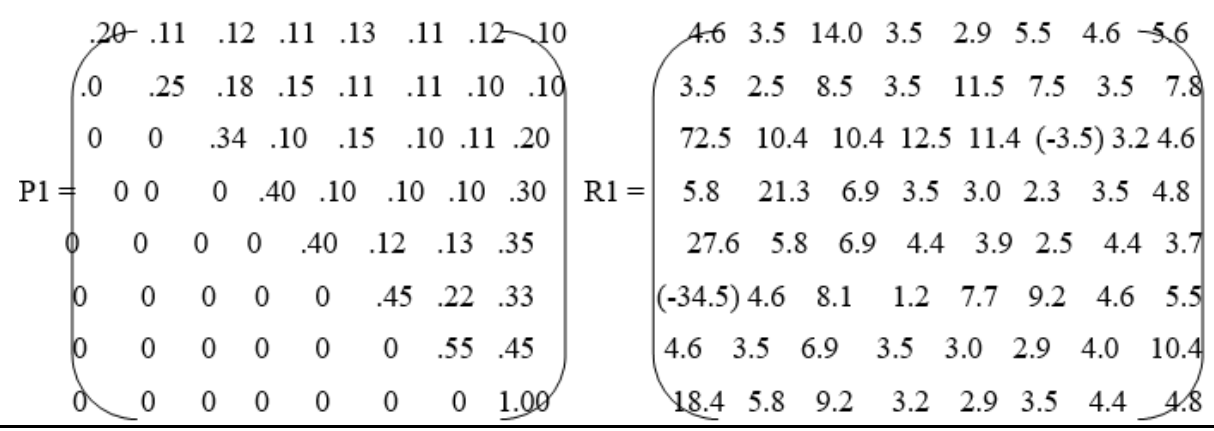

$$
\begin{aligned}
& \mathrm{V}^{\mathrm{s}} \mathrm{i} \\
& \mathrm{V}^{1}{ }_{1}=.20 \times 4.6+.11 \times 3.5+.12 \times 14+.11 \times 3.5+.13 \times 2.9+.11 \times 5.5+.12 \times \\
& 4.6+.10 \times 5.6=5.46 \quad \text { Irrigation } \\
& \mathrm{V}^{1}{ }_{2}=0 \times 3.5+.25 \times 2.3+.18 \times 8.1+.15 \times 3.5+.11 \times 11.5+.11 \times 7.8+.10 \times \\
& 3.5+.10 \times 7.8=5.81 \quad \text { Water Supply } \\
& \mathrm{V}_{3}^{1}=0 \times 72.5+0 \times 10.4+.34 \times 10.4+.10 \times 12.5+.15 \times 11.4+.10 \times(-3.5) \\
& +.11 \times 3.2+.20 \times 4.6=7.52 \\
& \text { Hydro Electric power generation } \\
& \mathrm{V}^{1}{ }_{4}=0 \times 5.8+0 \times 21.3+0 \times 6.9+.4 \times 3.5+.10 \times 3.0+.10 \times 2.3+.10 \times \\
& 3.5+.3 \times 4.8=3.72 \\
& \text { Flood Control } \\
& \mathrm{V}^{1}{ }_{5}=0 \times 27.6+0 \times 5.8+0 \times 6.9+0 \times 4.4+.40 \times 3.9+.12 \times 2.5+.13 \times 4.4 \\
& +.35 \times 3.7=3.73 \\
& \text { Drainage } \\
& \mathrm{V}^{1}{ }_{6}=0 \times(-34.5)+0 \times 4.6+0 \times 8.1+0 \times 1.2+0 \times 7.7+.45 \times 9.2+.22 \times 4.6 \\
& +.33 \times 5.5=6.97 \\
& \text { Navigation } \\
& \mathrm{V}^{1}{ }_{7}=0 \times 4.6+0 \times 3.5+0 \times 6.9+0 \times 3.5+0 \times 3.0+0 \times 2.9+.55 \times 4.0+ \\
& .45 \times 10.4=6.88 \\
& \text { Recreation } \\
& \mathrm{V}^{1}{ }_{8}=0 \times 18.4+0 \times 5.8+0 \times 9.2+0 \times 3.2+0 \times 3.2+0 \times 2.9+0 \times 3.5+0 \times \\
& 4.4+1 \times 4.8=4.8
\end{aligned}
$$

\begin{tabular}{|c|c|c|c|c|c|c|c|c|c|}
\hline $\mathrm{S}$ & $\begin{array}{l}\text { Irrigated } \\
\text { Agriculture } \\
\text { Пs1 }\end{array}$ & $\begin{array}{l}\text { Water } \\
\text { Supply } \\
\pi \mathrm{s} 2\end{array}$ & $\begin{array}{l}\text { Hydro- } \\
\text { Electric Power } \\
\text { Generation } \\
\pi \mathrm{s} 3\end{array}$ & $\begin{array}{l}\text { Flood } \\
\text { Control } \\
\pi s 4\end{array}$ & $\begin{array}{l}\text { Drainage } \\
\pi \mathrm{s} 5\end{array}$ & $\begin{array}{l}\text { Navigation } \\
\pi \mathrm{s} 6\end{array}$ & $\begin{array}{l}\text { Recreation } \\
\pi \mathrm{s} 7\end{array}$ & $\begin{array}{l}\text { Erosion } \\
\text { Control } \\
\pi \mathrm{s} 8\end{array}$ & $\begin{array}{l}\text { Expected } \\
\text { yearly } \\
\text { revenue } \\
\text { (Es) }\end{array}$ \\
\hline 1 & 0 & 0 & 0 & 0 & 0 & 0 & 0 & 1 & 4.80 \\
\hline 2 & .1248 & .0948 & .1269 & .1557 & .1689 & .1687 & .0984 & .0617 & 5.78 \\
\hline 3 & 0 & 0 & 0 & 0 & 0 & 0 & 0 & 1 & 4.80 \\
\hline 4 & 0 & 0 & 0 & 0 & 0 & 0 & 0 & 1 & 4.80 \\
\hline 5 & 0 & 0 & 0 & 0 & 0 & 0 & 0 & 1 & 4.80 \\
\hline 6 & 0 & 0 & 0 & 0 & 0 & 0 & 0 & 1 & 4.80 \\
\hline 7 & 0 & 0 & 0 & 0 & 0 & 0 & 0 & 1 & 4.80 \\
\hline 8 & 0 & 0 & 0 & 0 & 0 & 0 & 0 & 1 & 4.80 \\
\hline 9 & 0 & 0 & 0 & 0 & 0 & 0 & 0 & 1 & 4.80 \\
\hline 10 & .0193 & .0441 & .0671 & .0876 & .1158 & .1279 & .2292 & .3092 & 5.54 \\
\hline 11 & 0 & 0 & 0 & 0 & 0 & 0 & 0 & 1 & 4.80 \\
\hline 12 & 0 & 0 & 0 & 0 & 0 & 0 & 0 & 1 & 4.80 \\
\hline 13 & 0 & 0 & 0 & 0 & 0 & 0 & 0 & 1 & 4.80 \\
\hline 14 & 0 & 0 & 0 & 0 & 0 & 0 & 0 & 1 & 4.80 \\
\hline 15 & 0 & 0 & 0 & 0 & 0 & 0 & 0 & 1 & 4.80 \\
\hline 16 & 0 & 0 & 0 & 0 & 0 & 0 & 0 & 1 & 4.80 \\
\hline 17 & .0195 & .0443 & .0673 & .0884 & .1161 & .1284 & .2279 & .3085 & 5.52 \\
\hline 18 & 0 & 0 & 0 & 0 & 0 & 0 & 0 & 1 & 4.80 \\
\hline 19 & 0 & 0 & 0 & 0 & 0 & 0 & 0 & 1 & 4.80 \\
\hline 20 & 0 & 0 & 0 & 0 & 0 & 0 & 0 & 1 & 4.80 \\
\hline 21 & .0219 & .0446 & .0678 & .0884 & .1167 & .1292 & .2255 & .3059 & 5.50 \\
\hline
\end{tabular}

The computation of the stationary probabilities are achieved by using the equation of step 1 to 4 in section 3 Policy 2 yields the largest expected yearly revenue. The optimum long-range policy calls for application of maintenance regardless of the state of the River Basin Engineering Development from result on the table 4 policy 10.

Table 4 summarizes the results of $\pi^{\mathrm{K}}$ and $\mathrm{E}^{\mathrm{K}}$ for all the stationary policies 


\subsection{Conclusion}

The interpretation of results in policy 10 means that the eight objectives were optimal in multi-stages under the worst possible conflicting condition. That the policy 10 calls for application of maintenance whenever the system (River Basin Engineering Development) is in state 8 or very poor. The development should be apportioned by the planning and management Engineer as follows:

$\pi^{10} \quad$ Irrigated Agriculture

$\pi^{10}{ }_{2} \quad$ Water Supply

$\pi^{10}{ }_{3} \quad$ Hydro-Electric Power Generation

$\pi^{10}{ }_{4} \quad$ Flood Control

$\pi^{10}{ }_{5}$ Drainage

$\pi^{10}$ Navigation

$\pi^{10}{ }_{7} \quad$ Recreation

$\pi^{10} \quad$ Erosion Control

$\mathrm{E}^{10}$ represents expected yearly benefit:

When the River Basin Engineering Development is apportioned as above stated from the limited available fund of the Federal Government Budget of N 200billon, at least a (revenue) benefit of 1.108Trillion can be achieved under the worst condition of conflict objectives. It is recommended that the FMWR and Nigerian RBDAs should appear before a single Board of Directors that should be set up by the Federal Government for the implementation of the outcome of this research work using Markovian Decision models and this will resolve disagreements between Government and interest groups during project authorization. This work also advises a maintenance programme for the River Basin in accordance with the result of performance of the experiments such that the Basin operates a minimum of 8years and a maximum of 21 year for full capacity utilization of assets

\section{References}

Devine, E.J., (1966) "The Treatment Of Incommensurables In Cost-Benefit Analysis, Land Economics, Vol, 42 , N0 3, Pp:383-387.

Eme, L.C., (2012) "Simulation Modeling in Markovian Decision Theory in Multi-purpose/ Multi-objective River Basin Development Planning and Management" A Poster Presentation for the International Water Association World Water Congress at Bussan Korea

Eme L.C. (2012) "Simulation Modeling in Markovian Decision Theory in Multi-Purpose/Multi-Objective River Basin Engineering Development Planning and Management" A Ph.D Theses in the Department of Civil Engineering, Faculty of Engineering, Submitted to the School of Postgraduate Studies, Anambra State University .

Federal Military Government (1976) "River Basins Development Authorities Decree" Supplementary Official Gazette Extra Ordinary, 48, Vol, 66, 29 ${ }^{\mathrm{TH}}$ September Part A.

Hamdy, A.T., (2008) Operations Research: An Introduction Prentice Hall Of India, New Delhi-10001,

John, M., (2011) "Intergrated Governance and Water," Magazine of the international Water Association, June, pp53.

Jamie, P. (2011) “Twenty years on from Rio: where Management?" Magazine of the International Water Associative, water Environment 21, June, pp. 51-53

Ojiako, G.U,(1988) “A Useful Scientific Approach to Water Resources Planning In Nigeria”, The Nigerian Engineer, Vol. 20.No. 4, Pp. 13-25.

Ojiako G.U. (1985) "Analysis of Problems in the First Phase of Experimental Water Resources Management in Nigeria" Water Resources Vol. 1 N0.2, Oct. Pp. 216-220.

Ojiako, G.U., (1989) "Systems Concepts and Post-Optimality Analysis Applied to Water Resources Planning On Optimum Policy Criteria”, The Nigerian Engineer, Vol. 24 N0. 4 Pp. 71-78.

Ojiako, G.U., And Engerjuru, H. I., (2000) Mathematical Optimization Model For Conjunctive Operation Of Ground Water And Surface-Water Systems In Nigeria Unpublished Paper. 32.

Ouarda, T, B.M.J., (1991) Stochastic Optimal Operation of Large-Scale Hydro Power Systems (Colorado River),

U.S. Congress, (1971) Procedures for Evaluation of Water and Related Land Resources Projects, Senate Committee on Public Works, 92nd Congress, 1st Session, Pp. 6-11.

U.S. Water Resources Council, Special Task Force, (1970a) Principles for Planning Water And Land Resources Projects, Washington D.C.

U.S. Water Resources Council, Special Task Force, (1970b) A Summary Analysis of Nineteen Tests of Proposed Evaluation Procedures on Selected Water And Land Resources Projects, Washington D.C.

U.S. Water Resources Council, Special Task Force, (1977) Proposed Principles And Standards For Planning Water And Related Land Resources, Federal Register., Vol 36, N0. 245, Pp24, 144-24, 194. 